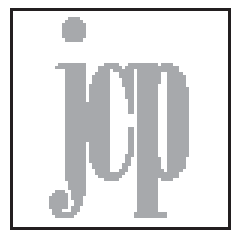

\title{
The Crescent on the Stage: Islam and Muslims in the Plays of two Elizabethan Dramatists
}

\author{
Mubashar Hassan Arif \\ University of Chakwal \\ mubasharhassan8383@gmail.com
}

\begin{abstract}
This article investigates the convention of Elizabethan Orientalism vis-à-vis historical, political, and cultural context of the period. Anglo-Islamic contact during the age of discovery is at the heart of this study. Since Queen Elizabeth consolidated strong economic and diplomatic alliance with the Muslim empires of the sixteenth and seventeenth centuries, her subjects exhibited special interest in the Orient. Two chief dramatists of the age, Shakespeare and Marlowe, staged their plays saturated with Islamic themes and characters. This study capitalises on the negative image of the Orient in the works of these writers. It is further argued that Elizabethan (mis) representations of the Orient were fraught with ambiguities. It witnesses that the Orients were always depicted as barbaric and uncivilised, the antipode of civilised Europe. Shakespeare and Marlowe, in their portrayal of Muslim characters, deviated from real historical facts and depicted them in a very despicable manner. They also employed many pejorative appellations for these characters. For example, ethnic terms like 'Turks' and 'Moors' were used for Muslim characters. These writers synonymised black people with tyranny and lechery. I have tried to read their plays in their true historical background. While Queen Elizabeth was establishing favorable relationships with the mighty Ottomans and the kingdom of Morocco, her writers were demonising and vilifying them. Most of the plays by Shakespeare and Marlowe translate Muslim characters on the stage as powerful and erotically alluring. It is also shown that these dramatists thrived on paradox and ambivalence.
\end{abstract}

Keywords: Anglo-Islamic, Encounter, Turks, Moors, Elizabethan Orientalism 
[T] he fear of being anachronistic should not keep us from investigating the history of racial difference.

Ania Loomba, Shakespeare, Race, and Colonialism, 2 It is a truth universally acknowledged, that a modern theoretical paradigm in possession of a wide currency must be in want of a medieval text.

Suzanne Conklin Akbari, Idols in the East, 5

This article examines Anglo-Islamic literary encounters from the sixteenth to seventeenth century in order to map out England's amicable diplomatic relationship with the rulers of Muslim Empires of the time Ottomans, Safavids, and North Africans. The field of Early Modern Orientalism had remained under considerable neglect ever since the publication of Samuel Chew's magisterial study The Crescent and the Rose (1937), and has lately been invigorated by formidable scholars like Nabil Matar, Gerald MacLean, Daniel Vitkus, Matthew Dimmock, Jonathan Burton, Emily C. Bartels, Bernadette Andrea, Linda Mcjannet, and Ania Loomba. Most of the plays staged during the age of discovery feature the EastWest binary at their centre. Through meticulous textual demonstrations, these writers have showcased Anglo-Islamic literary encounters during the Early Modern Period.

Edward Said's groundbreaking study Orientalism (1978) paved the way for literary historians to broach the history of racial differences between the Orient and the Occident. His book is still considered a landmark work in the field of literary studies, cultural anthropology, sociology and political science. He defines Orientalism as 'a style of thought based upon an ontological and epistemological distinction made between "the Orient" and (most of the time) "the Occident" (2). Said, further, argues that orientalism was institutionalised by "making statements about it, authorizing views of it, describing it, by teaching it, settling it, ruling over it: in short, Orientalism as a Western style for dominating, restructuring, and having authority over the Orient" (3). In his highly acclaimed book Covering Islam (1981), Said strongly asserts, "The norms of rational sense are suspended when discussions of Islam are carried on" (xix). Islam has always been constructed as a foil against which the West defined itself both religiously and culturally. Western/European civilizations have always maintained a relative insularity from the Orient ever since the first encounter. The kind of merger the West had with the Judeo-Christian world have not been established with the Islamic world.

My purpose here is twofold: on the one hand, to see how Anglo-Islamic alliance prospered and, on the second hand, how this alliance affected the way 
Islam and Muslims were staged in Elizabethan playhouses. It goes without saying that after her excommunication from the Roman Catholic Church in 1570, coupled with her kingdom's insularity from the rest of the Europe, Queen Elizabeth reached out to the mighty Ottoman and Moroccan Empires for diplomatic and commercial purposes and was the first ever Christian woman ruler to welcome Muslim ambassadors to Britain from Islamic lands. As Charles Beem's notes, "Elizabeth learned the rhetoric of empire from her exchanges with these Muslim sovereigns, who for the most part deemed her kingdom insignificant and herself a supplicant" (171).

Throughout the Tudor period, European diplomats, businessmen, travelers, and writers looked to the Islamic people in awe and wonder. They were mesmerised by the glamour of the lifestyle of the Muslim Kings. This amazement has been dubbed as 'imperial envy' by Gerald MacLean in his book Looking East (2007). He defines it in the following words:

When Queen Elizabeth ascended the throne, the English were a weak and relatively insignificant nation seeking to compete with the Spanish for the wealth of the New World. To the pious among the English, the Ottoman Empire was at once the great enemy and scourge of Christendom, yet to the commercially minded it was also the fabulously wealthy and magnificent court from which the sultan ruled over three continents with his great and powerful army. (21)

Confronted with Catholic Spain's looming threat, Queen Elizabeth resorted to the Moroccan ruler Mulay Ahmad al-Mansur and consolidated her alliance with the kingdom of Morocco. According to Matar, "Elizabeth was the first English monarch to cooperate with the Muslims and allow her subjects to trade and interact with them without being liable to prosecution for dealing with 'infidels'"(19). After contact with the vast empires of the Islamic East, Elizabethan people longed for similar empires for themselves. The early English travelers and ambassadors who visited Islamic dominions were surprised by Muslim rulers' grandeur. This desire further augmented when English traders found themselves at the mercy of the Ottomans and Barbary pirates in the multicultural Mediterranean. In their excellent work Britain and the IslamicWorld, 1558-1713, Matar and MacLean hold that for "Britons who only knew of Muslims and Islam from written sources, misunderstandings were bound to be numerous and widespread" (231).

Elizabeth exchanged letters and gifts with the Muslim rulers of her time. The Moroccan king Ahmad Al-Mansur was taken aback by Elizabeth's ideas and advanced his help against the dreaded foe Philip II of Catholic Spain. He was very clever and had it in his mind to retrieve erstwhile Al-Andalus (Muslim 
Spain) from Spain while Elizabeth wanted to protect her dominion from foreign invasion. Both rulers strove for their ends but neither succeeded, though England secured a naval victory over Spain, defeating the Spanish Armada in 1588 . In his famous study Britain and Barbary (2005), Matar quotes David Armitage saying, "[T]he English and later the Britons were driven toward motivation and discovery, not by the spirit of Protestant imperialism but by commercial need and greed" (5).

The English Queen had also developed a favorable diplomatic relationship with the mighty empire of the Ottoman Sultan, Murad III. Turks were all pervasive in the Eastern Mediterranean and were equated with terror. Turkish cruelty was vehemently despised and staged. Anglo-Ottoman relations reached its culmination in the multicultural Mediterranean where there was immense rivalry over the rightful imperial claims. England was a late entrant in the commercially expanding Mediterranean, and, in Barbara Fuchs' words, "[P]ainfully conscious of its imperial belatedness with respect to Spain" (7). During the age of discovery, Muslims were defined in ethnic terms, for example they were called 'Moors', 'Turks', and 'Saracens'.

Jonathan Burton notes, "[I]n the period between 1579 and 1624 over sixty dramatic works featuring Islamic themes, characters, or settings were produced in England" (11). The pioneering work in the field was done by Samuel Chew in his magisterial The Crescent and the Rose, written in 1937. The most horrendous portrayal on the Tudor stage was that of the 'Turk'. The Ottoman Empire was a dreaded military power and Ottoman Turks were dreaded and hated in Europe. The Ottoman Sultan was considered as the incarnation of the devil. Europeans have several different fantasies about the Sultan. For them, he was very lustful and despotic whose rule nobody could defy. The Ottomans first set foot in Europe in 1529 when they invaded Vienna and it culminated with the second siege in 1683 . Had they not been stopped by the Polish king John III Sobieski, they would have conquered the whole of Europe. In the European imagination, Turks were uncontrollable rascals whose lecherous behavior had no bounds.

As a result of the Anglo-Moroccan alliance, numerous black people came to England. As the trafficking between the two countries increased, there also developed a sense of aversion towards these foreigners among the Queen's masses and they started complaining against these intruders. At the same time, there were massive food shortages in England and these foreigners were accused of this scarcity. When pressure mounted on the Queen, she ordered for their expulsion from her dominion. Drama flourished during the Elizabethan Period especially 
from 1570 to 1630 . As it was the main source of information, many people used to come to different playhouses in London and elsewhere and would entertain themselves in exotic settings of the plays. It is, however, important to mention that the dramatists of the age were very much aware of their Queen's amiable alliance with the Islamic rulers of her time and they staged that relationship in their magnum opuses. Since the English nation was in the process of defining its national identity, these writers played on various stereotypes. According to Jerry Brotton, "throughout the Tudor period a powerful set of misrepresentations, misconceptions and misunderstandings developed which defined relations between the two faiths" (9).

Many merchants and traders achieved great success in Islamic lands; their stories were received with great amazement back in England. Another phenomenon that heavily influenced the relationship between England and Muslim lands was captivity. There were sea pirates who attacked English ships in the Mediterranean and took people hostage and demanded hefty ransoms for their release. Back in England, the public was asked in the churches to collect money and pay back the pirates and get their men released. This situation held sway for a long period of time. On the one hand, Elizabeth was trying to consolidate her relations with the Muslim rulers while on the other hand, her people were unsettled by the threat of capture and captivity. In his fabulous book Turks, Moors and Englishmen in the Age of Discovery (1999), Matar confirms, "it was only English theological and literary texts that betrayed hostility to Muslims: it was the stereotype developed in literature that played the greatest role in shaping anti-Muslim national consciousness" (13). Nevertheless, he provocatively avers, "simplification and stereotyping were the rules by which Britons represented Muslims" (116).

As the relationship between the Queen and Islamic rulers blossomed, Islamic characters popped up on the Elizabethan stage. Many critics speculate that Shakespeare drew inspiration for Othello from Abd al-Wahid bin Masoud bin Muhammad al-Annuri, a potent ambassadorial representative who came to England in order to conclude an Anglo-Moroccan alliance. Shakespeare has been considered a canonical playwright among all the Elizabethan dramatists with whom the East-West dichotomy plays out very beautifully. Many of his plays are saturated with Islamic themes and characters, the chief among them are Titus Andronicus, The Merchant of Venice, Othello, and The Tempest. There are innumerable allusions to the 'Orient' in all his plays. 


\section{Shakespeare's Islam}

Matthew Dimmock, one of the most redoubtable scholars on Anglo-Islamic literary encounters in the Early Modern Period, writes, "Without Islam there would be no Shakespeare" ("Shakespeare and Islam"). Reference to the king of Morocco and Sultan Solyman in The Merchant of Venice, Turning Turk and Barbary horse in Othello, Caliban in The Tempest, perfumes of Arabia in Macbeth, Amurath in Henry $V$ are some important instances of the bard's engagement with the Muslim world of his time. If these Oriental references were not there, his plays would not have been as beguiling and captivating. Daniel Vitkus holds, "there are twenty 'Mediterranean' plays in Shakespeare's canon" (39).

A striking reference to the king of Morocco is found in The Merchant of Venice where the heroine, Portia, tests her suitors in winning her in marriage - a trial suggested by her father to test the allegiance of her suitors. There are three caskets and one casket contains the picture of the beautiful heroine. The one who will select the casket which hides the picture of the sweet Portia will win her hand in marriage. There appears a 'black' Moroccan King who, like the previous suitor, selects the golden casket and ultimately loses the precious and sane Portia and disappears from the scene. The black king brags about his heroic deeds in war against the mighty Ottoman Sultan and the ruler of Persia. His valorous boastfulness transforms into fancy when he pledges to win Portia

By this scimitar

That slew the Sophy, and a Persian prince

That won three fields of Sultan Solyman.

$$
\text { (2.1.25-27) }
$$

The spectators were not unmindful of the fact that nobody could dare to slay Sophy, the prince of Persia as well as kill Sultan Suleyman the Magnificent. Nonetheless, here comes a Moroccan combatant in a European country laying claim to have routed the mighty Ottomans and the Persian ruler. Although these diplomatic exchanges were exclusive and were confined to the Queen's innermost coterie, yet one marvels how far this awareness reached and entered into the domain of public sphere.

Nevertheless, upon choosing the wrong casket, the black king is met by a typical pernicious Elizabethan prejudice (against the Moors) by the clever female heroine who says:

A gentle riddance. Draw the curtains, go,--

Let all of his complexion choose me so.

$$
\text { (2.7. 78-79) }
$$

There seems no likely reason why there should be a black Moroccan in a comedy 
mainly dealing with the moneylender Shylock and Venetian Christian traders. For staging Muslims in his plays, Shakespeare resorted to two precedents that were available to him. One example can be found in Robert Wilson's Three Ladies of London in which Gerontus, a venerable Jewish moneylender, registers his protest against the falsity of Mercadorus - a vicious Christian merchant - in front of a Turkish judge. The second instance is present in Marlowe's famous play The Jew of Malta in which Barabas, the Jew, schemes a harrowing plot against the Maltese Christians. He forges an alliance with the Turkish black slave Ithamore. However, Shakespeare took the road less tread upon by staging the Jew and the Moor who are not saintly figures, but are disenfranchised unrelentingly by the Christian characters. Muslims and Jews have always been conflated and deemed apostates and heretics in Christendom.

There also appears a Moor, as a minor character, in the bard's most heartrending tragedy Titus Andronicus. The Queen of Goths, Tamora, is captured and brought to Rome by Titus. Aaron, a black moor and lover of the queen accompanies her to her captivity. In the course of events that unfold, Aaron is shown as an epitome of villainy and barbarity. He is an evil genius. He wreaks immense havoc and brings about disaster for so many people. Shakespeare's black characters are the earliest Early Modern stereotypes to encapsulate black men as lecherous, lustful, inordinate and evil incarnate. They also inform about Renaissance England's anxieties about the Muslim Other. Another important Elizabethan dramatist George Peele also staged black characters in his plays. Shakespeare's black characters are proximately modelled on Peele's moor. Some critics also speculate that Shakespeare collaborated with Peele in writing his black characters. Aaron conflates his villainy with the dark color of his skin. While assisting Titus to cut his hand off, he disdainfully calls his soul black:

O how this villainy

Doth fat me with the very thought of it

Let fools do good, and fair men call for grace

Aaron will have his soul black like his face.

\section{(3.1.205-208)}

In the play, Aaron's actions resemble that of Barabas' despicable and vile actions in Marlowe's The Jew of Malta (1589-1590). By the end of the play when he is enquired about his heinous crimes and asked if he is not ashamed of his monstrous deeds, he replies:

Ay, that I had not done a thousand more.

Even now I curse the day-and yet I think

Few come within the compass of my curse- 
Wherein I did not some notorious ill, As kill a man, or else devise his death, Ravish a maid, or plot the way to do it, Accuse some innocent and forswear myself, Set deadly enmity between two friends, Make poor men's cattle break their necks, Set fire on barns and haystacks in the night, And bid the owners quench them with their tears.

(5.1.126-136)

This would have been an anticipated end of a villain whose insensate violence was so profound that he is entombed alive. Aaron showcases all the evils and fears associated with his non-Christian character. However, by conflating Aaron with Barabas, Shakespeare conflates him with Turks and Jews as well as Moors. In the final rush of things when Aaron is brought in front of Titus' sole surviving son Lucius, he pledges to divulge everything if the Romans will allow his illegitimate son to live on. Lucius rules out his request.

Possibly the most well-known character who represents Islam in English literature is Shakespeare's eponymous hero Othello, a tawny Moor, who is pitted against the mighty and dreadful Ottomans. The setting of the play is Venice when the city of Cyprus is under imminent threat of being besieged by the appalling Ottoman Turks. Since Othello is hailed for his military prowess and temerity in the Venetian state, he is sent to save the city from the onslaught of the Turks. Othello's complexion is the very source of his hatred in the hearts of white characters in the play, especially Iago. Although he converted to Christianity at a young age, Desdemona's (a Senator's daughter) elopment with the Moor causes suspicion among the Venetians about the Moor's likely predilection for sorcery, since a Venetian girl could never marry any person from a non-white race. At one point, Desdemona's father, Brabantio, lashes out at Othello with derision and accuses him of seducing his daughter by using black magic which is the very essence of his black race. The Senator is at a loss to understand how his daughter has:

Run from her father to the black bosom

Of a thing such as you, to fear, to delight in?

$$
\text { (1.2. 70-71) }
$$

Elizabethan texts, more than often, equated internal and external foes, synonymising the sultan with Satan. In Protestant England, it was held that Satan and the Turk wished to 'convert' pious Protestant masses to a position of damnation. Shakespeare's Othello taps into Protestant England's fears and anxieties about expanding Ottomans. It can safely be assumed that Elizabethan England was not, in any way, under the imminent threat of Islamic Empires, but the dramatists of 
the age often alluded to the Turkish menace. Othello was staged many times at the English court and received good deal of attention as it pandered to contemporaneous enchantment with the 'alien', both Turks and Moors. A similar attraction is played out in Masque of Blackness authored by Ben Jonson and Inigo Jones. A huge bulk of literature was produced in England on/against the Ottomans. One very famous example is Richard Knolles's Generall Historie of the Turkes published in 1603. The opening pages allude to "The glorious Empire of the Turkes, the present terror of the world". Since the Ottomans were expanding further and further into Europe and the Balkans and were also consolidating their position in the Mediterranean, these reports reached back to England and stamped their success. In broaching the specificity of Othello's epithet, that is, 'the Moor', G. K. Hunter deliberates on the word: “'The Moor' was very vague ethnographically, and very often seems to have meant little more than 'black-skinned outsider,' but it was not vague in its antithetical relationship to the European norm of the civilized white Christian" (51). Many texts written by the Europeans during the period under study, feature North African Moors as perfidious, lecherous, and faithless. In order to present Othello as an impulsive and hasty tragic hero, Shakespeare resorted to the available racial vocabulary of his time.

The most contested representation of any Moor is in the dramatic romance The Tempest (1611). The story is set on an island where the king, Prospero, banished by his brother from his rightful place of kingship, is stranded on an island along with his daughter Miranda. Upon settling on the island, Prospero manages to kill the black Caliban's mother, Sycorax, with the help of his magic aide Ariel. After her murder, Prospero becomes the sole overseer of the island (recall Robinson Crusoe by Daniel Defoe). Caliban, the child of the island's prior female ruler, becomes his servant and succumbs to his will. Whenever he tries to exercise his own will, he is beaten down by the magic aide Ariel. At one point, Caliban endeavors to woo Miranda but is severely punished by Prospero. Caliban wants independence from the European lord, Prospero, but he is withheld from his liberty. He reiterates his pretentions on the island saying:

This Island's mine, by Sycorax my mother Which thou takest from me.

$$
\text { (1.2.334-35) }
$$

In an aggressive verbal assault, Miranda berates him by calling him: "A Abhorred slave', 'capable of all ill, 'savage', 'A thing most brutish', and that of 'vile race'” (1.2. 356-65). It is also very much evident that all European characters consider Caliban worthless and his identity remains fluid and unstable till the end of the 
play. Although he is linguistically empowered by the Europeans (Miranda teaches him the English language) but he is not given the real freedom. Finally, when all the whites are ready to leave the island, Prospero, to others' sheer disgust, admits:

[T]his thing of darkness I

Acknowledge mine.

\section{(5.5. 275-76)}

Shakespeare was also inimical to the Turks and their barbarity. During the reign of Queen Elizabeth, stories of Turkish cruelty were widespread and it was assumed that upon acceding to the throne, Turkish kings murdered their brothers and other siblings so that no one could lay claim to the kingdom of the Ottoman Empire. This phenomenon is referred to in the play Henry $V$. When Henry succeeds to the throne, he consoles his brothers by saying:

Brothers, you mix your sadness with some fear.

This is the English, not the Turkish court;

Not Amurath an Amurath succeeds,

When Prince Henry is victorious, he registers peace with the French by betrothing Catherine. The resentment of the European regal family against the 'Turks' is a phenomenon most obviously evinced in HenryV (1599) when Prince Henry implores the French queen:

Shall not thou and I, between Saint Denis and Saint George, Compound a boy, half-French half-English,

That shall go to Constantinople and take the Turk by the beard?

$$
\text { (5.2. 215-218) }
$$

Islam was constructed as a foil against which the West defined itself both religiously and culturally in opposition to the Orient. The West always maintained a relative insularity from the Orient. The kind of merger the West had with the Judeo-Christian world could not be maintained with the Muslim World. Islamic empires had a unique identity which sharply contrasted with that of the Christian Other. They were culturally more versatile, politically more vibrant, and economically more prosperous. Benedict S. Robinson holds that "between the 1580 s and the 1630s, the Levant Company controlled England's most important trade routes and was itself the site of the most explosive economic growth" (117). In the plays of a great number of Early Modern dramatists, we find witness denigration of these Islamic people. In reality, Muslims were unconquerable but in the imaginatively-controlled environment of the theatre, they were fabricated and reviled. Shakespeare's plays display the ways in which Christian English audiences 
may have viewed themselves against the image of Muslim men.

\section{Christopher Marlowe's Orientalism}

Marlowe was also a bigwig among the chief dramatists of his age. He followed Shakespeare's footsteps and wrote some of the finest plays of the age. Among them the chief plays are Doctor Faustus, Tamburlaine I and II, and The Jew of Malta. The Jew of Malta is very intriguing because the story pivots around a Jew, Barabas, who lends money. When the Turks come to collect tribute from the state of Malta, Barabas is imposed upon to give half of his wealth to the Turks. The Turkish collector is Selim-Calymath, the son of the Ottoman Sultan. Upon refusal, his whole wealth is confiscated by the state. He connives with Selim and assists him in conquering the island. But, by the end of the play, all non-Christian characters get embroiled in Ferneze's (Malta's governor's) seductive scheme and are blasted. Before dying, Barabas utters awful imprecations both on Christians and Turks:

Damned Christians, dogs, and Turkish Infidels!

In the play The Jew of Malta, Selim Calymath is presented as highly dis agreeable because of his extortionist designs against the Maltese. He vociferously demands the delayed tribute and warns of serious repercussions for defying the Sultan's authority. The image of Selim Calymath as an aggressor and extortionist implicitly demeans the entire Islamic Officialdom and demonise the sultan. This vilification of sultan is the outcome of the prevalent prejudice and bias of the Christians against the Muslims particularly in the context of the crusades and their long-lasting consequences. In his essay Mythologizing the Ottoman: The Jew of Malta And The Battle of Alcazar, Leeds Barroll observes: "And just as Malta, contrary to impressions given by Marlowe's play, never fell to Ottomans, Cyprus, contrary to the scenario painted in Othello, had been in Ottoman hands since 1570 and was not retaken in Shakespeare's lifetime — not, indeed, until the nineteenth century. (120).

In the second part of the play, Tamburlaine invests a lot of his time in profaning deities including the Prophet of Islam. By reading Marlowe's plays one can easily construe that he had an extensive awareness of medieval Islamic theology. We find an allusion to the 'Zoacum' tree (Act II, scene iii) which implies that he might have waded through the Quran (the reference to this aforementioned tree is present in Chapter 37 of the divine scripture). At the start of the second part, Orcanes, the lieutenant to the eponymous hero, inscribes a treaty of 
peace with Hungary's king Sigismund, pledging:

By sacred Mahomet, the friend of God,

Whose holy Alcoran remains with us,

Whose glorious body, when he left the world,

Clos'd in a coffin mounted up the air

And hung on stately Mecca's temple roof,

I swear to keep this truce inviolable.

Tamburlaine is the most controversial play by Marlowe and is based on a Central Asian King, Timur. Throughout the play, as we see, he keeps on usurping all the neighboring lands and is the sole dreadful monarch of the East. He defeats Mycetes, the king of Persia, and then heads for Bajazeth, the emperor of the Turks and defeats him also. Bajazeth and his wife are enslaved by Tamburlaine, and in his captivity, the Turkish emperor is humiliated and degraded and finally he commits suicide. Christian writers of the Elizabethan period conflated Prophet Muhammad with God, as Bajazeth swears:

By Mahomet, my Kinsman's sepulcher,

And by the holy Alcoran I swear

He shall be made a chest and lustless eunuch,

And in my sarell tend my concubines:

And all his captains that thus stoutly stand,

Shall draw the chariot of my emperess,

Whom I have brought to see their overthrow.

(Tam. 1, 3.3. 75-81)

Compelled by Bajazeth's excruciating defeat, his wife Zabina also calls upon Prophet Muhammad:

Now, Mahomet, solicit God himself,

And make him rain down murdering shot from heaven

To dash the Scythians' brains, and strike them dead

That dare to manage arms with him

That offered jewels to thy sacred shrine

When first he warred against the Christians.

(Tam. 1, 3.3. 195-200)

Marlowe's anti-Islamic streak seems to be quite evident and he is no second to Shakespeare as far as scanty knowledge of Islam is concerned. For instance, in Tamburlaine I and II, the Morning Star of the Elizabethan Period conflates Prophet Muhammad with a deity and consecrates him for his divine powers. This is highly fallacious as Prophet Muhammad is only a clairvoyant of God. Scholars are unclear about the precise nature of sources for both Tamburlaine plays. There are many mysteries and all are shrouded in academy's tower. The 
plays' immense popularity owes its debt to various myths about Timur the Lame (1336-1405) who was known to London public for his temerity and heroic deeds. Both plays are saturated with references to the contemporary political upheavals. In order to reach at the heart of spice trade and Asia, early modern European travelers navigated through Russia. There are many chronicles which attest to this phenomenon. These trade routes were championed by explorers like Anthonie Jenkison and cemented by Richard Hakluyt. According to Dimmock, "Tamburlaine presents a relentless catalogue of goods and trading locations reminiscent of the reports of Jenkinson and others that begins to open the east to the English mercantile gaze" (New Turkes 136).

During both parts of Tamburlaine we find a proclivity for Persia at the expense of the Ottomans. Although the English were interested in Ottoman-Safavid wars, they wished for the Ottomans' victory as English diplomats sought military help from the Ottomans. By giving prominence to the Persians, Marlowe endorsed James I's favored policy of friendship towards the Persians. James I vehemently despised the Ottomans and did not sign even a single commercial letter. Marlowe's denigration of the Turkish emperor Bajazeth in Tamburlaine (part I), hedges around the Ottoman-Persian conflict. From the start, Bajazeth is exhibited as tyrannical and pompous. Unlike the real Bajazeth who was a great warrior and emperor, Marlowe's Bajazeth is meek and flexible. Both parts of Tamburlaine are fraught with tensions. During the course of the play, the eponymous hero serves the Christian cause and speaks on behalf of Christians. For example, in Part I, he says:

I that am termed the scourge and wrath of God,

The only fear and terror of the world,

Will first subdue the Turk and then enlarge

Those Christian captives which you keep as slaves,

And feeding them with thin and slender fare

That naked row about the Terrene Sea,

And when they chance to breath and rest a space

Are punished with Bastones so grievously

That they lie panting on the galley's side

And strive for life at every stroke they give.

$$
\text { (Tam. I, III.iii. 44-54) }
$$

Dimmock avers that:

Not only does this extract seem rather uncharacteristic of Tamburlaine in both its concern for 'those Christian captives' and its length and detail, but it is again anachronistic - those 'straggling runagates', and 'cruel pirates of Argier' were a sourse of considerable contemporary anxiety and an impediment to continued trade in the region and had been written about from 
first-hand experience by Englishmen like Edward Webbe who had also travelled in Persia. (New Turkes 145)

By staging such contentions on the stage, Marlowe embeds his material with contemporary political turmoil surrounding Early Modern England. Interestingly, the eponymous hero's assertion, "the scourge and wrath of God", followed by his intention to "subdue the Turk" before assisting Christian captives, implicitly insinuates Tamburlaine's position as the scourge of God for Muslim Turks not Christian pagans. The links get further cemented after the crushing defeat and humiliation of Bajazeth, as he accepts:

Now will the Christian miscreants be glad,

Ringing with joy their superstitious bells

And making bonfires for my overthrow.

Ere I die, those foul idolaters

Shall make me bonfires with their filthy bones.

(Tam. I, III. Iii. 236-240)

Marlowe finishes part I with the demise of Bajazeth. After his death, the eponymous hero has got no enemy to fear. Marlowe then, again, draws out confrontations between Christians and Turks. Orcanes says:

Forgett'st thou I am he

That with the cannon shook Vienna walls

And made it dance upon the continent,

As when the massy substance of the earth

Quivder about the axletree of heaven?

(Tam. II, I.i.86-90)

According to Dimmock:

Orcanes's revelation that he had personally led the advance upon, and siege of Vienna, is another example of the way in which the conscious anachronistic transplantation of near contemporary political and military concerns and events into the source material is specifically designed to both enhance and add urgency to these traditional oppositions." (New Turkes 149)

Turks and Moors, as characters, appear in a number of plays written during the period under scrutiny. The most telling examples are George Peele's The Battle of Alcazar, Christopher Marlowe's The Jew of Malta, Shakespeare's Titus Andronicus and Othello, Thomas Heywood's Faire Maid of West and Thomas Dekker's Lust's Dominion. All these dramatists subscribe to the lascivious stereotype of the Turk and Moor inherent in the English imagination since the first encounter. There is a common parallel thread of villainy in these plays. Brotton avers that "[a]t a theological level Christendom had always conflated Muslim and Jews as apostates who denied Christ as the Son of God, heretics representing two sides of the same religious error"(204). 
The most dangerous and confrontational image of Islam and Muslims staged by the Elizabethan dramatists has directly yielded from their insecurity and fear of Muslims principally because of the captivity narrative widely propagated by the English religious, literary and historical imagination. British merchants and traders during their travels to Ottoman-controlled lands met fellow Christians who were under religious and physical subjection to an Islamic state. Besides these, Elizabethan dramatists knew Islam from written sources which were often misleading as even the most learned of the scholars could not put aside their prejudice against Islam and presented such works before the English readers so as to make them imagine that Islam was the most potent threat to the godly Christians. During the Elizabethan period, most of the trade and expeditions headed towards France and Spain rather than the Islamic Mediterranean. This indicates that much of the nullification of Muslims by the Elizabethan dramatists is based on the publication of dozens of stories about battles with Turks and Moors in which Islam acquires a generalised picture of an aggressively violent religion. To a great extent Muslim scholars and writers are responsible for this anti-Islam opinion of the Elizabethan playwrights as they have not produced any scholarly work to correct these prejudices.

The clash between Islam and the European world is not culturally and politically driven, rather it is theological. But in the modern world, this conflict has translated into the domain of science and technology. By alluding to the works of many dramatists, I have shown how Elizabethan England was in awe and admiration of the Muslim World of its time. The Queen and her countrymen equally sought good commercial and diplomatic relationship with the rulers of the Islamic Empires. But, at the same time, the playwrights were engaged in stigmatising these very people. As England was under the constant threat of an invasion from Spain, they resorted to the Ottoman Sultan and Moroccan ruler Ahmad Al- Mansur for military aid. On the stage, however, the 'Moors' and 'Turks' were abused. The Turks were depicted as cruel, lustful, brutal, tyrannical, and deviant while the Moors are charged with overflowing sexuality and bestiality. Furthermore, black people are also shown as vengeful and sentimentally uncontrollable. 


\section{Works Cited}

Akbari, Suzanne Conklin. Idols in the East: European Representations of Islam and the Orient, 1100-1450. Cornell University, 2009.

Brotton, Jerry. This Orient Isle, Elizabethan England and the Islamic World. Penguin Random House UK, 2016.

Burton, Jonathan. Traffic and Turning, Islam and English Drama, 1579-1624. University of Delaware Press, 2005.

Dimmock, Matthew. New Turkes, Dramatizing Islam and the Ottomans in Early Modern England. New York: Routledge, 2005.

---. "Shakespeare and Islam." OUP blog, 18 Dec. 2015, https://blog.oup.com/2015/12/shakespeare-and-islam/ .

Fuchs, Barbara. Mimesis and Empire:The new World, Islam, and European Identities. Cambridge University Press, 2003.

Gerald M. MacLean, Nabil Matar. Britian and the IslamicWorld, 1558-1713. Oxford: Oxford University Press, 2011.

Hunter, G. K. English Drama 1586-1642:The Age of Shakespeare. Oxford University Press, 1997.

Knolles, Richard. The Generall Historie of the Turkes: From the First Beginning Of that Nation to the Rising of the Ottoman Familie: with All the Notable Expeditions of the Christian Princes Against Them. 1603.

URL:https: / /quod.lib.umich.edu/cgi/t/text/text-idx?c $=$ eebo;idno $=$ A04911.0001.001

Loomba, Ania. Shakespeare, Race, and Colonialism. New York: Oxford University Press, 2002.

MacLean, Gerald. Looking East, EnglishWriting and the Ottoman Empire before 1800. Palgrave Macmillan, 2007.

Robinson, Benedict S. Islam and Early Modern English Literature. New York: Palgrave Macmillan, 2007.

Said, Edward. Covering Islam: How the Media and the Experts Determine how We See the Rest of theWorld. New York: Vintage Books, 1981.

---. Orientalism. New York: Penguin, 1978.

Shakespeare, William. King HenryV. Ed. J. H. Walter. Methuen, London, 1954.

---. Othello:Authoritative Text, Sources and Contexts, Criticism. W.W. Norton \& Co, 2004. Print.

---. The Merchant ofVenice. Eds. Burton Raffel \& Harold Bloom. Yale University Press, 2006.

---. The Tempest. Ed. Frank Kermode. Arden Shakespeare, 1954. Print. 
---. Titus Andronicus. Eds. Barbara A. Mowat \& Paul Werstine. Folger Shakespeare Library, 2021.

Vitkus, Daniel. Three Turk Plays From Early Modern England. Columbia University Press, 2000.

-. Turning Turk, English Theater and the Multicultural Mediterranean, 1570-1630. Palgrave Macmillan, 2003. 